\title{
Insurers are not Banks: Assessing Liquidity, Efficiency and Solvency Risk Under Alternative Approaches to Capital Adequacy
}

\author{
Paul Kupiec ${ }^{\mathrm{a}}$ and David Nickerson ${ }^{\mathrm{b}}$ \\ ${ }^{a}$ Center for Financial Research, Federal Deposit Insurance Corporation, Washington DC, U.S.A. \\ ${ }^{\mathrm{b}}$ School of Accounting and Finance, Roosevelt University, Chicago, IL, U.S.A. \\ E-mail: dnickerson@roosevelt.edu
}

\begin{abstract}
Differences in the portfolios of depositories and insurance and reinsurance firms are important for the design of efficient capital regulations. Using a simple contingent claims model which focuses on credit risk and in which intermediaries issue liabilities under conditions of moral hazard, we illustrate three effects of risk-based capital regulations on institutional solvency risk, liquidity and economic efficiency. First, assuming identical asset risks to depositories, insurers that issue significant amounts of contingent liabilities may exhibit a zero risk of insolvency while holding significantly less equity capital than depositories. Second, higher capital requirements must be placed on depositories to attain the same degree of solvency risk, owing to the riskless payoffs promised for bank deposits and similar liabilities. Third, while bank-based capital regulations cannot resolve losses associated with systemic financial risk, capital regulations that incorporate incentive-compatible tax penalties to mitigate moral hazard effects can do so by increasing both liquidity and spanning. We conclude that distortions occur when measuring the solvency risk of insurers and other non-bank intermediaries with bank-based capital regulations and that uniform harmonization of capital regulations across depositories and insurers can significantly reduce aggregate liquidity and efficiency.
\end{abstract}

The Geneva Papers (2005) 30, 498-521. doi:10.1057/palgrave.gpp.2510038

Keywords: Basel; capital regulation; credit risk; contingent claims; banking; insurance

Jel classification: G21; G22; G28; G33; H21; H23

\section{Introduction}

Financial policymakers and regulators are increasingly concerned with systemic risk, the potential for a modest economic shock to induce substantial volatility in asset prices, significant reductions in liquidity, bankruptcies and aggregate losses in wealth and efficiency. Such instability arises from acute uncertainty regarding the ability of key financial institutions to satisfy their immediate payment obligations and a simultaneous inability of counterparties to hedge such risk. Regulatory capital requirements for such institutions could enhance financial stability, if they mitigate the risks to solvency inherent in the portfolios 
of financial institutions and so create confidence on the part of financial counterparties. $^{1}$

Capital regulations based on the original Basel Accord (BCBS, 1988) and, more recently, on the Basel II proposals (BCBS, 2004), are the focus of many financial stability discussions, since these agreements set uniform minimum regulatory capital standards for internationally active depositories ("banks"). While the solvency risk of internationally active banks and bank-holding companies is clearly important, banks are only one type of financial intermediary active in international risk-exchange markets. An erosion of confidence in a key non-bank intermediary, such as a large insurance or reinsurance firm ("insurers"), could also have significant consequences for systemic risk. ${ }^{2}$

Several varieties of non-bank intermediaries, including insurers, face capital regulations with minimum solvency standards that differ markedly from those applied to internationally active banks. While these institutions may meet or exceed their minimum regulatory capital requirements, they may simultaneously appear to be undercapitalized relative to capital standards for internationally active banks. The perception of significant deficiencies in the capitalization of some non-bank intermediaries, particular large insurers and related firms, relative to existing or proposed Basel standards, has been identified as a potential source of systemic risk by prominent policymakers.

Greenspan, ${ }^{3}$ Davies, ${ }^{4}$ Knight, ${ }^{5}$ among others, have discussed the benefits of "harmonizing" capital regulations for all types of financial institutions to promote stability and to preclude the possibility of "regulatory arbitrage" between banks, insurers and other types of non-bank intermediaries. Virtually all calls for harmonization appear to promote the view that the approach underlying bank capital requirements should be applied to insurers as well as other types of intermediaries. ${ }^{6}$ In

\footnotetext{
${ }^{1}$ This stability objective is clearly articulated in the U.S. Federal Deposit Insurance Corporation's Manual of Exam Policies (FDIC, 2000): "Capital provides a measure of assurance to the public that an institution will continue to provide financial services even when losses have been incurred, thereby helping to maintain confidence in the banking system and minimize liquidity concerns."

${ }^{2}$ Such concerns are clearly reflected in a report by the Group of Ten (2001), "... non-bank financial institutions, not just banks, have the potential to be sources of systemic risk...even a medium-sized foreign bank (or perhaps a non-bank financial institution) from a large nation would be a potential source of instability to a relatively small host country". The Group of Ten's findings echo those of the influential "Tietmeyer Report" (Tietmeyer, 1999): "Systemic threats can also arise ... from difficulties at non-bank financial institutions and large insurance companies".

${ }^{3}$ Greenspan (1998).

${ }^{4}$ Davies (2001a, b, 2002).

${ }^{5}$ Knight (2004).

${ }^{6}$ Keefe (2002) documents the explicit advocacy, by the FSA Director of Operational, Insurance and Group Risk, of the harmonization of capital regulations for all financial institutions, including banks, insurers and investment and securities firms, under a single regime based on the principles of the Basel II accord (2004), a position also evident in Sharma (2002). Basel-based approaches to measuring solvency risk are also clear in the FSA (2004) 190, recently incorporated into the FSA Prudential Sourcebook for insurance regulation, and in the preliminary proposals incorporated in the Solvency II initiative for insurance regulation throughout the European Union (European Commission, 2002). See Guy Carpenter (2004) and Hohlfeld (2004) for additional details.
} 
recent studies and commentary, other representatives of regulatory agencies, including Booth, ${ }^{7}$ Sharma ${ }^{8}$ and Tiner ${ }^{9}$ in the U.K., and Gensler, ${ }^{10}$ Fisher, ${ }^{11}$ and Poole ${ }^{12}$ in the United States (U.S.), have examined the capital adequacy of various types of insurers and reinsurers, notably the mortgage securitization firms Fannie Mae and Freddie Mac, using bank regulatory standards. Assessed under banking standards, these intermediaries appear to be significantly undercapitalized and a potential source of systemic risk.

Those advocating harmonization cite the risks of "regulatory arbitrage", in which differences in financial sector capital regulations promote investment concentrations that are alleged to decrease stability in the financial sector. Within this policy discussion, no formal analysis has been presented that justifies the unification of regulatory capital requirements for all financial intermediaries under a bank standard. Moreover, differences in regulatory capital standards may create or reinforce incentives that motivate differences in portfolio composition between banks and insurers; for example, the policy discussion includes only a presumption that these differences increase systemic risks. Insurers, as we demonstrate, can in particular be well-capitalized, with a risk of insolvency no greater than that of banks, and still appear to be seriously undercapitalized relative to bank capital regulations. Studies that document such findings, consequently, do not necessarily provide evidence that regulatory arbitrage has undermined financial sector stability.

This paper analyzes the design of regulatory capital policies for two types of alternative financial intermediaries - "banks" (representing all types of depositories) and "insurers" (insurance and reinsurance institutions) in a simple model in which the incentives created by moral hazard for each type of intermediary mandate capital regulations to mitigate credit risk. We contrast the design of respective capital requirements for a representative bank and a representative insurer when each regulatory regime is designed to eliminate the risk of default by either intermediary on its liabilities, without unduly limiting the volume of liabilities issued by that intermediary. We distinguish between banks and insurers by the nature of their liabilities: banks issue deposits, which are required to pay their par value across all future states of nature, and insurers issue contingent (insurance) contracts, which pay contractual claims only in a specified subset of future states. We assume that banks and insurers are otherwise similar, sharing identical investment opportunities and managerial expertise, and abstract from comparative differences in monitoring or the ability to manage trading relationships with counterparties.

We demonstrate, in the context of a simple equilibrium model, that when the risks of asset portfolios are held constant, bank solvency requires higher capital requirements

\footnotetext{
${ }^{7}$ Booth (2002).

${ }^{8}$ Sharma (2002)

9 Tiner (2002).

${ }^{10}$ Gensler (2000).

${ }^{11}$ Fisher (2002).

12 Poole (2002).
} 
than are necessary for an insurer whose liabilities promise only state contingent payoffs. Although the proof is provided in the context of a simple finite state model with one source of risk (credit risk), the conclusions are general and will apply in richer models where financial institutions face multiple risk factors. The analysis clearly demonstrates that, in general, it is inappropriate to use a bank regulatory standard to judge the capital adequacy of an insurer funding its investments with a significant amount of liabilities that include explicit or embedded contingent claims.

Since the bulk of bank liabilities are deposits, payable on demand with equal value in all states of nature, banks must face capital requirements that are far more demanding than those required by insurers with contingent liability structures. Since capital regulations for banks are designed to preclude default risk from bank deposit liabilities, significant inefficiencies may arise should these capital guidelines be uniformly applied to insurers and related intermediaries. When an insurer's liabilities are contingent and structured to attenuate its risk of insolvency given its assets' risk profile, the insurer's risk of insolvency can be minimal and yet it may appear to be significantly undercapitalized relative to a regulatory capital requirement that is optimal for banks. Many insurers and related intermediaries use structured debt issues as a form of risk management. Examples include catastrophe bonds, callable debt issues, reinsurance agreements, and health and property-casualty insurance contracts themselves.

The paper is organized as follows. The next section reviews selected evidence of the increasing participation by banks and insurers in the same global markets for risk and the increasing frequency with which the two types of intermediaries serve as counterparties in risk exchange. The section "A model of solvency risk and capital regulation" introduces our simple model of intermediated financial exchange and establishes respective regimes of prudential capital regulations for banks and insurers which ensure that each type of intermediary exhibits zero risk of insolvency. The section "Liquidity, efficiency and capital requirements for banks and insurers" explains why the equity-asset ratios implied by bank regulations are so much higher than that for insurers, for a common degree of solvency risk, examines why these types of capital regulations cannot resolve the losses in liquidity and hedging opportunities (spanning) from the market incompleteness caused by moral hazard, and examines how alternative, incentive-compatible regulations for capital adequacy can increase liquidity and hedging by serving to make bank and insurer portfolios transparent to investors. A final section concludes the paper.

\section{Risk market participation by banks and insurers}

Owing to the globalization of both real and financial trade, large depositories and other types of financial intermediaries, such as insurers and reinsurers, increasingly participate in the same international markets for financial risk. The growth in derivative transactions has, in particular, greatly expanded risk management opportunities available to both banks and insurers. International markets for derivatives, which have grown rapidly over the last two decades, exhibit particularly notable growth in the bilateral trade of specialized, over-the-counter 
(OTC) contracts. These increasingly feature banks and insurers serving as counterparties to each other.

To illustrate the relative extent of participation in global risk-sharing by large depositories and bank-holding companies, along with a variety of nonbank financial firms, and the diversity of their respective regulators, Table 1 presents data on the asset size and notional stock, in U.S. dollars (USD), of all derivative contracts open at yearend 1999 and year-end 2000 for a sample of 34 of the largest bank-holding companies, securities dealers and insurance and reinsurance firms, which reported derivative positions in SEC filings or other public disclosures for these dates. ${ }^{13}$ Firms are ranked by derivative size in 2000, and the primary regulators for the firms, and country of incorporation, are also shown. The data in Table 1 show that, while JPMorganChase Manhattan, whose bank-holding company activities are regulated by the Federal Reserve Board, was engaged in the largest volume of derivative transactions in both years, securities firms such as Merrill Lynch, Morgan Stanley and Lehman Brothers, whose primary regulator is the SEC, and European Union financial conglomerates such as Deutsche Bank, BNP Paribas, UBS Warburg and Barclays PLC, comprised seven of the largest 10 derivative users in the sample. Insurance and reinsurance firms, including AIG, regulated by the SEC and U.S. state insurance commissioners, and FannieMae and FreddieMac, regulated by OFHEO, also appear in the top 25 users.

Internationally active insurance and reinsurance firms, while generally smaller than the firms in Table 1, also have a significant presence in global derivative markets and resemble other varieties of financial intermediaries in their usage of derivatives, relative to (asset) size. Table 2 presents data on the disclosed notional stock, in USD, of derivative contracts open at year-end 1999 by those six of the 11 largest traditional international insurance and reinsurance firms that publicly reported derivative activity throughout 1999 . Although the notional contract value for these insurance firms $(9,272,886,337$ USD) was modest relative to that for most of the institutions reported in Table 1, the data reveal substantial differences across insurers in their notional derivative holdings, and also an average proportional holding of derivatives, relative to firm size, comparable to those firms appearing in Table 1.

Finally, Table 3 illustrates the large and increasing frequency with which large banks and bank-holding companies appear as counterparties in OTC derivative contracts with insurers. Specific values are reported, in year-end 1994 and 1999, respectively, for the 10 banks and bank-holding companies that most frequently served as counterparties in such OTC derivative contracts with insurers in each respective

\footnotetext{
${ }^{13}$ We note that reinsurance firms include, on economic grounds, two of the three U.S. housing GSEs, Fannie Mae and Freddie Mac, since the charter of each requires it to act as a reinsurer of credit risk in a regulated class of residential mortgages. We also note that financial and bank-holding company (FHC/ BHC) parents of U.S. investment banks and securities dealers in Table 1 include Deutsche Bank AG (DB Alex Brown and Taunus), Citigroup (Salomon, Smith, Barney Holdings), Barclays PLC (Barclays Capital), CIBC (CIBC World Markets), Bank of Montreal (Nesbitt Burns and Harris Bank), Dresdner AG (Dresdner, Kleinwort, Benson NA) and Nomura Holdings (Nomura Securities International). Details of these balances are given in Kupiec and Nickerson (2002).
} 
Table 1 Risk market participation by large financial institutions

\begin{tabular}{|c|c|c|c|c|c|}
\hline \multirow[t]{2}{*}{ Firm } & \multicolumn{2}{|c|}{ Assets } & \multicolumn{2}{|c|}{ Derivatives } & \multirow[t]{2}{*}{ Regulator } \\
\hline & 2000 & 1999 & 2000 & 1999 & \\
\hline JPMorganChase & 715,348 & 667,003 & $24,526,022$ & $21,812,900$ & FRB (U.S.) \\
\hline Deutsche Bank AG & 875,112 & 845,744 & $9,066,715$ & $7,654,199$ & BAKred (Germany) \\
\hline BNP Paribas & 592,733 & 703,599 & $7,810,911$ & $7,430,370$ & CRBF/CM (France) \\
\hline Citigroup & 902,210 & 716,937 & $7,813,851$ & $7,351,197$ & FRB (U.S.) \\
\hline Bank of America Co. & 642,191 & 632,574 & $7,521,960$ & $5,127,219$ & FRB (U.S.) \\
\hline Merrill Lynch & 383,904 & 329,554 & $5,313,890$ & $3,939,000$ & SEC (U.S.) \\
\hline UBS Warburg & 679,998 & 616,428 & $5,151,499$ & $5,619,394$ & CFDB (Switzerland) \\
\hline Morgan Stanley & 421,279 & 366,967 & $4,529,631$ & $3,404,000$ & SEC (U.S.) \\
\hline Barclays PLC & 472,230 & 411,442 & $4,525,490$ & $2,732,869$ & FSA (U.K.) \\
\hline Lehman Brothers & 225,668 & 192,244 & $3,752,600$ & $2,895,650$ & SEC (U.S.) \\
\hline HypoVeriensbank & 674,670 & 506,748 & $1,860,450$ & $1,570,308$ & BAKred (Germany) \\
\hline Wachovia & 328,202 & 259,757 & $1,142,715$ & 631,344 & FRB (U.S.) \\
\hline CIBC & 178,587 & 172,447 & 995,994 & $1,263,387$ & OSFI (Canada) \\
\hline Goldman Sachs & 289,760 & 250,491 & 942,152 & 809,205 & SEC (U.S.) \\
\hline Bank of Montreal & 155,675 & 159,788 & 935,526 & 811,035 & OSFI (Canada) \\
\hline Dresdner AG & 232,871 & 204,348 & 929,834 & 795,602 & BAKred (Germany) \\
\hline Bank One & 269,300 & 269,425 & 807,639 & $1,031,089$ & FRB (U.S.) \\
\hline Nomura Holdings & 141,125 & 122,407 & 729,005 & 632,314 & FSA (U.K.) \\
\hline Bear Stearns & 171,200 & 162,000 & 596,900 & 622,300 & SEC (U.S.) \\
\hline $\mathrm{AIG}$ & 426,671 & 383,685 & 521,021 & 413,357 & NYID/SEC (U.S.) \\
\hline FHLBS & 583,212 & 434,002 & 494,621 & 382,421 & FHFB (U.S.) \\
\hline FreddieMac & 459,297 & 386,684 & 467,281 & 409,920 & OFHEO (U.S.) \\
\hline FleetBoston Financial Corp. & 179,519 & 190,692 & 391,726 & 292,250 & FRB (U.S.) \\
\hline FannieMae & 675,072 & 575,167 & 324,812 & 251,570 & OFHEO (U.S.) \\
\hline Bank of New York & 77,114 & 74,756 & 312,311 & 316,689 & FRB (U.S.) \\
\hline HSBC North America & 104,299 & 90,240 & 239,232 & 202,544 & FRB (U.S.) \\
\hline Wells Fargo & 272,426 & 218,102 & 231,921 & 221,005 & FRB (U.S.) \\
\hline CSFB Securties/DLJ & 103,751 & 109,012 & 163,600 & 130,900 & SEC (U.S.) \\
\hline State Street Co. & 69,298 & 60,899 & 143,666 & 131,251 & SEC (U.S.) \\
\hline KeyCorp & 87,165 & 83,344 & 79,913 & 65,364 & FRB (U.S.) \\
\hline National City & 88,535 & 87,121 & 59,926 & 57,349 & FRB (U.S.) \\
\hline ABN Amro North Am & 96,753 & 63,743 & 52,203 & 53,520 & FRB (U.S.) \\
\hline Mellon Financial Corp. & 50,564 & 48,227 & 45,058 & 54,932 & FRB (U.S.) \\
\hline Metropolitan Life & 255,018 & 225,232 & 13,477 & 20,834 & NYID/SEC (U.S.) \\
\hline
\end{tabular}

Selected end-of-year balance sheet, derivatives and regulatory data, ranked by magnitude of notional OTC derivatives contracts outstanding in 2000 and denominated in millions of nominal U.S. dollars, for a sample of the 50 financial firms most active in OTC derivatives transactions and serving as counterparties to U.S. financial institutions, including financial and bank holding companies (FHC/BHC), insurance/reinsurance firms and U.S. housing GSEs, in 1999 and 2000. Data are listed for domestic or international parent of U.S. securities firm or FHC/BHC when data are unavailable on subsidiary, with associated primary regulator of parent institution and country of origin. Primary regulators for firms in the sample are: Federal Reserve Board (FRB), Securities and Exchange Commission (SEC), New York and other U.S. state insurance departments (NYID), coordinated through National Association of Insurance Commissioners (NAIC), Bundesaufsichtsamt für das Kreditwesen (Federal Banking Supervisory Office (BAKred)), Banking and Financial Regulatory Committee, Ministry for Economic Affairs and Finance/Banking Commission of Banque de France (CRBF/CM), Commission Fédérale des Banques (Swiss Federal Banking Commission), Financial Services Authority (FSA), Office of the Superintendent of Financial Institutions, Ministry of Corporate and Consumer Affairs Canada (OSFI), Federal Housing Finance Board (FHFB), and Office of Financial Housing Enterprises Oversight (OFHEO). 
The Geneva Papers on Risk and Insurance - Issues and Practice

504

Table 2 Risk market participation by international insurers and reinsurers

\begin{tabular}{lrrr}
\hline Firm & Assets & Derivatives & Proportion (\%) \\
\hline Allianz & 380,448 & 8,680 & 2.28 \\
Munich RE & 178,772 & 2,993 & 1.67 \\
Swiss RE & 108,947 & 26,671 & 24.48 \\
AON & 21,132 & 6,507 & 30.79 \\
Marsh and McLennan & 13,021 & 387 & 2.97 \\
Allied Zurich & 9,563 & 10,399 & 108.74 \\
\hline
\end{tabular}

Selected on- and off-balance sheet data for six of the 11 largest international insurance and reinsurance firm, ranked by asset size, reporting the notional stock of OTC derivatives contracts open at the end of 1999.

Assets and notional OTC derivatives contracts outstanding are denominated in millions of U.S. dollars. Proportion $(\%)$ measures the ratio of the outstanding notional derivatives stock to asset size in percentage terms.

year. ${ }^{14}$ Although data on the relative market share of each bank, as counterparty, are not reported here, it is notable that the number of insurers and reinsurers using the 10 most popular banks has significantly increased over the 5-year reporting period.

\section{A model of solvency risk and capital regulation}

While capital requirements designed for depositories, such as those in Basel I and Basel II, focus on the credit risk exhibited by the assets held by a bank, other types of financial intermediaries, such as health and property-casualty insurers and reinsurers, may hold assets similar to those of banks but, in contrast to banks and other depositories, fund such assets through contingent liability (insurance) contracts rather than deposits. When the state-contingent nature of liabilities exerts a significant influence on the overall solvency risk of a financial intermediary, capital requirements that focus on assets alone can yield a seriously biased assessment of that intermediary's risk of default on its liabilities. Regulating such intermediaries through capital requirements designed for the liability structures of depositories can also cause real efficiency losses to the economy, in the form of restrictions on both liquidity and on the portfolio opportunities available to investors. We use a simple numerical version of the generic finite state space model of the exchange of consumption claims, based on

\footnotetext{
${ }^{14}$ Owing to the recent implementation of FAS 133 derivatives reporting requirements for SEC filings in the U.S., derivatives usage data for nonbank firms is rare and available only for limited samples. Firms operating in the European Union have to date also been reluctant to provide such data in public filings. Insurance firms in the U.S., however, are required to report derivatives transactions to the state insurance commission in each state in which they conduct life or property/casualty books of business. These data, compiled by the National Association of Insurance Commissioners in the U.S., underlie the comparisons in Table 3. Specifically, the results for 1994, taken from Cummins, Phillips and Smith (1996), consist of the universe of all life and property-casualty insurers filing regulatory annual statements with the NAIC for 1994, while the results for 1999 were analogously compiled by the authors for this same universe of all life and property-casualty firms, the reports for which appear in the NAIC DB database (NAIC, 2000) for 1999.
} 
Table 3 Risk market transactions between banks and insurers

\begin{tabular}{lclc}
\hline & & & 1994 \\
\hline Counterparty & $\begin{array}{c}\text { Insurers using } \\
\text { counterparty }\end{array}$ & Counterparty & $\begin{array}{c}\text { Insurers using } \\
\text { counterparty }\end{array}$ \\
\hline Deutsche Bank & 99 & Credit Suisse & 27 \\
UBS & 79 & Chemical Bank & 21 \\
Credit Suisse & 78 & Barclays Bank & 20 \\
Bank of America & 51 & Citibank & 18 \\
Barclays Bank & 39 & Chase & 15 \\
Banque Paribas & 31 & Deutsche Bank & 14 \\
Citibank & 31 & UBS & 12 \\
ABN Amro & 23 & Royal Bank of Canada & 11 \\
Credit Lyonnais & 11 & Bank of America & 10 \\
Bank One & 10 & Bank One & 8 \\
\hline
\end{tabular}

The 10 internationally active banks most heavily used as counterparties, in OTC derivative contracts, by insurance and reinsurance firms operating in the United States, as of year-end 1994 and 1999.

Werner ${ }^{15}$ and Milne, ${ }^{16}$ and incorporating a simple form of moral hazard and the presence of bank and non-bank intermediaries, to illustrate both of these propositions.

\section{The model}

Consider a two-date, finite-state economy in which all contingent claims are traded at date zero and claims payoff at date zero. We assume that individuals who invest at date zero and consume at date zero exhibit standard continuous and complete preference orderings, represented by a concave utility function, with regard to consumption opportunities across states; that consumption sets are unbounded below; and that no arbitrage opportunities exist at date zero. ${ }^{17}$ All traded securities and contingent claims can, consequently, be valued as if agents are risk neutral. ${ }^{18}$ The riskfree rate is arbitrarily normalized to zero and the units of claims traded are arbitrarily labelled euros.

${ }^{15}$ Werner (1987).

16 Milne (1995).

${ }^{17}$ Werner (1987) and Milne (1995) describe a complete set of assumptions regarding consumer preferences and the convexity and closedness of each consumer's consumption set and a proof of the existence of an equilibrium price vector for current and future claims on consumption in the absence of a bounded consumption set, for an exchange economy with a finite set of states and an asset span of arbitrary dimension.

${ }^{18}$ We do not necessarily assume that all agents are risk neutral, needing only the result that assets can be priced as if agents are risk neutral after an appropriate change of measure, reflected in the distribution given in Table 3. Harrison and Pliska (1981) establish that the absence of arbitrage in a discrete time and discrete state space model implies the existence of a risk-neutral pseudo-probability measure and the equivalent martingale valuation condition. Owing to incomplete spanning in our model, this risk-neutral probability measure exists but may not be unique. Assuming that the measure exhibited in markets is common knowledge among all individuals, however, this non-uniqueness does not compromise our results if the relative ranking of state probabilities is invariant across potential alternative measures. 
506

Since the assumption of a finite number of alternative states of nature at date zero is essential, we further simplify the model, for expositional clarity and without loss of generality, by arbitrarily limiting the number of alternative states to seven. The economy features a single consumption good at date zero, with an endowment of claims on this good in each of the seven states. Under these assumptions, the date zero value of contingent claims and securities is simply equal to the expected value, at date zero, of the claims on real production generated across states on date zero.

Moral hazard is introduced into this economy by specifying that the distribution or endowment profile of claims across states at date one, tradable at date zero, is generated as a convex combination of two fundamental distributions across states. Any feasible combination corresponds to a particular pattern of investment at date zero. Again, for ease of exposition, we refer to each of these fundamental distributions as a production process for date one claims across states, and identify each such distribution as being generated by a distinct type of "project", respectively denoted as types A or B. ${ }^{19}$ Assuming that each entrepreneur ("firm") in the economy possesses one and only one project, a firm type is simply identified by the project it holds. Only intermediaries, and the firm itself, are aware of a firm's type, with neither investors nor regulators being able to distinguish firm types. The total number of all firms is arbitrarily fixed at 100 , with 50 holding type A projects. The aggregate production of claims from all firms and the individual production of each firm type is stochastic and is characterized by the seven-state distribution described in Table 4. Under our assumptions, all investors evaluate the value of each firm type, as well as the market value of all claims, by calculating expectations with respect to the risk-neutral probabilities also specified in Table $4 .{ }^{20}$

The claims (production in each state) generated by type A and type B firms are perfectly symmetric with respect to aggregate production in the economy: type B firms produce a greater share of output in states 1-3, while type A firms produce the larger output shares in states 5-7. The minimum date one production is 1.50 euros for either firm type, occurring in state 1 for a type A firm and in state 7 for a type B firm. Under these conditions, type A and B firms have identical market values at date zero, before uncertainty is resolved, and this shared value, common knowledge to all agents, is simply the expectation of each firm type's output under the distribution in Table 4, equal to 8 euros. The asset span of this economy, as indicated in Table 4, has dimension four, relative to seven distinct states of nature, and, consequently, asset markets are incomplete.

Finally, we assume in this economy with incomplete asset markets that investment by individuals in either firm type can only be undertaken through a financial

\footnotetext{
19 The "firm", consequently, simply refers to the asset generating the distribution of claims at date one, and could be interpreted as the distribution of returns to a commercial loan, a mortgage, or any other asset.

${ }^{20}$ Although the presence of intermediaries in our model is consistent with exchange under moral hazard (Spulber, 1996), we take their presence as given and focus on how alternative regulation of such intermediaries affects the volume of claims traded in the economy, rather than deriving their emergence endogenously in the manner of Diamond (1984). We also assume that all firms can successfully obtain loans from intermediaries at market prices, and, for ease of exposition, assume each firm obtains one loan.
} 
Table 4 The model economy

\begin{tabular}{lcccc}
\hline State & Probability & $\begin{array}{c}\text { Type A project } \\
\text { production }\end{array}$ & $\begin{array}{c}\text { Type B project } \\
\text { production }\end{array}$ & $\begin{array}{c}\text { Aggregate } \\
\text { asset values }\end{array}$ \\
\hline 1 & 0.05 & 1.5 & 4.5 & 300 \\
2 & 0.10 & 4 & 9 & 650 \\
3 & 0.20 & 5 & 12 & 850 \\
4 & 0.30 & 10 & 10 & 1,000 \\
5 & 0.20 & 12 & 5 & 850 \\
6 & 0.10 & 9 & 4 & 300 \\
7 & 0.05 & 4.5 & 1.5 & 800 \\
Aggregate market value & & & 8.00 \\
Individual project value & 8.00 & & \\
\hline
\end{tabular}

Risk-neutral distribution of period one states of nature and state-contingent production by both project type and aggregated across all firms, with corresponding period zero market values for individual project types and for aggregate production.

intermediary. An intermediary extends a loan of value identical to either a type A or a type B firm at date zero, financing through the issuance of equity and of liabilities purchased by individual investors at the market prices implicit in Table 4. Two generic types of financial intermediaries, distinguished by the nature of their liabilities, are assumed to exist. The first, termed a "bank", funds its loan portfolio with deposits and equity. The second, resembling an insurance or reinsurance firm, is termed an "insurer", and funds its loan portfolio with equity and through the sale of contingent contracts, similar to property casualty, health or credit-risk insurance contracts. Payoffs to such contracts are contingent on one and only one of the four values of aggregate production observable in period one.

Each firm successfully finances its project through a loan from a single intermediary at date zero, each such loan having an arbitrary par value of 5 euros, with a current market value equal to the common cost of A and B projects. A loan of specified par value to either firm type exhibits an identical probability of default, loss given default, and default option value. A 2 euro par value pure discount loan for type A and B firms carries, as shown in Table 5, a date zero market value equal to 4.70 euros, the expected value of the actual payments made to a lender, by either type of firm, across all states. The contingent value of default, 0.3 euros, equals the difference between the par and market values of the loan, and is in turn equal to 6.38 per cent of the market value of the loan, which is the market yield.

\section{Capital requirements under asymmetric information}

We can now compute the optimal regulatory capital requirements that apply under different approaches for regulating the two types of intermediaries, banks and insurers, assuming each intermediary possesses an identical asset portfolio. We assume that the objective of regulators is to minimize the solvency risk of either type of intermediary, ensuring that the respective types of liabilities issued by these different 
The Geneva Papers on Risk and Insurance - Issues and Practice

508

Table 5 Loan pricing and default characteristics

\begin{tabular}{|c|c|c|c|c|c|}
\hline State & Probability & $\begin{array}{l}\text { Par value for } \\
\text { project A loan }\end{array}$ & $\begin{array}{l}\text { Par value for } \\
\text { project B loan }\end{array}$ & $\begin{array}{c}\text { Payoff on project } \\
\text { A loan }\end{array}$ & $\begin{array}{c}\text { Payoff on project } \\
\text { B loan }\end{array}$ \\
\hline 1 & 0.05 & 5 & 5 & 1.5 & 4.5 \\
\hline 2 & 0.10 & 5 & 5 & 4 & 5 \\
\hline 3 & 0.20 & 5 & 5 & 5 & 5 \\
\hline 4 & 0.30 & 5 & 5 & 5 & 5 \\
\hline 5 & 0.20 & 5 & 5 & 5 & 5 \\
\hline 6 & 0.10 & 5 & 5 & 5 & 4 \\
\hline 7 & 0.05 & 5 & 5 & 4.5 & 1.5 \\
\hline \multicolumn{4}{|c|}{ Market value of loan } & 4.70 & 4.70 \\
\hline \multicolumn{4}{|c|}{ Default option value ( $\%$ market value) } & 6.38 & 6.38 \\
\hline \multicolumn{4}{|c|}{ Default probability } & 0.20 & 0.20 \\
\hline
\end{tabular}

Loan default distribution and risk-neutral valuation for loans, with a par (maturity) value of 5 , made to a firm with either a Type A or Type B project.

intermediaries will never be in default and limiting the exposure to such default on the part of any explicit or implicit public guarantee fund.

\section{Bank regulation: ensuring the safety of deposits}

We assume that banks fund their operations with deposits, promising to pay their par value in all states of nature, and that bank regulators wish to ensure the safety of bank depositors and limit either expected insurance costs under a formal government deposit guarantee scheme or any implicit benefits that may accrue to banks under an implicit guarantee system. Regulatory capital requirements, consequently, bind the leverage of a bank.

A deposit will risklessly pay its par value in every state of nature if and only if that value is no greater than the minimum production of either project type across all states of nature. This minimum value is, as specified in Table 4, equal to 1.5. A deposit used to finance a loan to a firm will, consequently, be riskless if the bank is restricted to funding $\operatorname{Min}[1.50, \mathrm{par}]$ of the current loan value with the deposit or, equivalently, if the loan is subject to a regulatory capital requirement of par-Min $[1.50$, par $]$, where par denotes the par value of the loan. Additional loan value in excess of 1.50 must be entirely financed, in the absence of other bank liabilities, with equity.

This maximum deposit-to-loan capital requirement ensures the safety of deposits without requiring regulatory knowledge of the type of firms represented in bank loan portfolios. No matter what degree of leverage banks offered to type A or type B firms, the proceeds from the bank loans would ensure that deposits are risk free under this minimum capital rule. A bank making a 5 euro par value loan with a current market value of 4.7 euros would, for example, be required to have an equity capital of 3.20 euros per loan, equivalent to a risk-based capital requirement of 68.09 per cent. If 100 firms operate in this economy, aggregate available liquidity, the total endowment of riskless claims issued by banks and available for trading by investors at date zero, is 150 euros. 
Owing to moral hazard opportunities available to intermediaries, this capital requirement foregoes potential liquidity benefits from the diversification of bank lending across firm types. An example of the potential diversification benefits for the provision of risk-free deposits appears in Table 6. If a bank were to actually diversify its loan portfolio, making simultaneous paired loans of equal par value to type A and type B firms, then, because the minimum joint output of these two firms types across all states of nature is 6 euros, a pair of such loans could support $\operatorname{Min}[6, \mathrm{par}]$ units of risk-free deposits. The diversification from the paired loan strategy would allow a substantial increase in liquidity, with banks able to double (to 300 euros) the aggregate value of riskless claims available for trade at date zero.

Moral hazard arises when only banks, rather than regulators or investors (depositors), can distinguish type A and B firms at date zero. If this asymmetry was common knowledge to all participants and if capital requirements were relaxed to capture diversification benefits, banks could conceivably finance every pair of 5 euro (or greater) loans with six euros of deposits. The value to bank shareholders of the call option inherent in their equity would, however, induce bank shareholders to concentrate the bank's loans to a pair of firms of the same type while representing, to regulators and investors, the portfolio of the bank as diversified. If depositors relied on an explicit guarantee provided in conjunction with regulatory oversight, losses to the guarantee fund would occur in some states of nature. An ex ante gain of 0.15 euros per pair of 5 euro loans would, in the example in Table 6 , accrue to bank shareholders from concentrating their loan portfolio, since the public guarantee allows depositors to act as if each deposit of 6 euros was valued at par, when the market value of such a deposit would be 5.85 euros in the absence of the guarantee. Investors will, in such an absence, discount any deposit of value larger than Min[1.50, par] the maximal funding constraint corresponding to the 68.09 per cent capital requirement required for riskless deposits; a bank will never hold a diversified portfolio if it wants to issue such a deposit. Owing to moral hazard, consequently, regulators will maintain the 68.09 per cent bank capital requirement and force investors to forego the liquidity benefits associated with a doubling of riskless deposits, if this benefit is less, per loan pair, than the transfer of 0.15 euros from the public guarantee fund to bank shareholders. ${ }^{21}$

Insurance regulation: ensuring the integrity of state-contingent liabilities

Although moral hazard also prevents markets from spanning uncertainty in the model economy, insurance intermediaries can issue (insurance) contracts with payoffs

\footnotetext{
${ }^{21}$ While we assume that banks are prohibited from issuing risky liabilities, such as subordinated debt, a bank could obviously, in theory, use such liabilities to reduce its capital requirement, subject only to fair market pricing restrictions and a credible regulatory promise to ensure strict priority of depositors' claims in the case of bankruptcy, although moral hazard would again induce the bank to hold a concentrated loan portfolio in equilibrium, as shown in Kupiec and Nickerson (2002). We limit the current analysis to pure deposit financing, since bank regulators have historically acted to minimize bank default on any liabilities, a practice explicitly noted in Basle Committee on Banking Supervision (1999).
} 
Table 6 Deposit value and loan diversification

\begin{tabular}{|c|c|c|c|c|}
\hline \multirow[b]{2}{*}{ State } & \multicolumn{2}{|c|}{ Concentrated bank lending } & \multicolumn{2}{|c|}{ Diversified bank lending } \\
\hline & $\begin{array}{c}\text { Payout on two par } 5 \\
\text { loans for separate } \\
\text { type A projects }\end{array}$ & $\begin{array}{c}\text { Payout on single } \\
6 \text { euro bank } \\
\text { deposit }\end{array}$ & $\begin{array}{c}\text { Payout on par } 5 \text { loan to } \\
\text { each of type } A \text { and type } \\
B \text { projects }\end{array}$ & $\begin{array}{l}\text { Payout on single } 6 \\
\text { euro bank deposit }\end{array}$ \\
\hline 1 & 3 & 3 & 6 & 6 \\
\hline 2 & 8 & 6 & 9 & 6 \\
\hline 3 & 10 & 6 & 10 & 6 \\
\hline 4 & 10 & 6 & 10 & 6 \\
\hline 5 & 10 & 6 & 10 & 6 \\
\hline 6 & 10 & 6 & 9 & 6 \\
\hline 7 & 10 & 6 & 6 & 6 \\
\hline \multicolumn{2}{|c|}{ Deposit value } & 5.85 & & 6.00 \\
\hline \multicolumn{2}{|c|}{ Default option value } & 0.15 & & 0.00 \\
\hline \multicolumn{2}{|c|}{ Default probability } & 0.05 & & 0 \\
\hline
\end{tabular}

Risk-neutral values of 6 euro bank deposits used to finance respective diversified and non-diversified portfolios with corresponding value to banks of deposit default options.

contingent, as illustrated in Table 4, on the realization of the mode of the distribution of aggregate production or on any one of the three pairs of states corresponding to the remaining observable values of such production. We assume, analogous to the case of banks, that regulators impose minimum capital requirements for each insurer in order to preclude default on the state-contingent payoffs associated with insurance contracts and to minimize claims on public funding of any associated system of guarantees.

Minimum capital requirements for insurers consist of a maximum number of unitary (one euro) contracts, per observable production value, with which the insurer funds a single loan. Table 7 describes the respective funding restrictions that ensure that no insurance contract can be in default and, equivalently, that each insurer is free of solvency risk. These restrictions limit the representative insurer to fund a loan with no more than 1.5 euros from contracts paying out when aggregate production in period one is 300 (i.e., in states one or seven), plus no more than 4 euros from contracts paying out when aggregate production is 650 (i.e., in states two and six), and so on. ${ }^{22}$

Since the risk-neutral probabilities represent state-contingent prices, these bounds on the use of contingent (insurance) contracts to fund loans translate directly into an equity capital requirement for the insurer. Table 8 illustrates the situation of an insurer purchasing a pure discount bond with a par value of 5 euros from either type of firm. Such an insurer can use 4.45 euros in sales revenue (insurance premia) in funding this loan, which itself has, at these same prices, a period zero market value of 4.7 euros. The equity an insurer must use to fund the residual current loan is, consequently, 0.25

\footnotetext{
${ }^{22}$ Analogous to bank regulations, maximum permissable sales of contingent liabilities by insurers will also be the maximum possible sales the market would value as riskless in the absence of regulation. Insurers would pay a credit risk discount on contracts exceeding this level since investors could not verify a claim of portfolio diversification without information about insurer assets.
} 
Table 7 Regulatory liability limits for representative insurer

\begin{tabular}{lcl}
\hline $\begin{array}{l}\text { Aggregate } \\
\text { production event }\end{array}$ & $\begin{array}{c}\text { States of } \\
\text { nature }\end{array}$ & $\begin{array}{l}\text { Maximum value of contingent contract } \\
\text { financing per loan }\end{array}$ \\
\hline 300 & 1,7 & Min[loan par value, 1.5] \\
650 & 2,6 & Min[loan par value, 4] \\
850 & 3,5 & Min[loan par value, 5] \\
1000 & 4 & Min[loan par value, 10] \\
\hline
\end{tabular}

Regulatory maximum liability funding schedule for a representative insurer or reinsurer for each project loan, under risk-neutral distribution of state-contingent production across all firms.

Table 8 Implied regulatory equity capital for representative insurer

\begin{tabular}{|c|c|c|c|c|c|c|c|c|}
\hline State & Probability & $\begin{array}{c}\text { Payment } \\
\text { on a par } 5 \\
\text { loan to type } \\
\text { A firm }\end{array}$ & $\begin{array}{c}\text { Payment } \\
\text { on a par } 5 \\
\text { loan to type } \\
\text { B firm }\end{array}$ & $\begin{array}{c}\text { Maximal } \\
\text { funding by } \\
\text { contingent } \\
\text { contract: }\end{array}$ & $\begin{array}{l}\text { Residual } \\
\text { insurer } \\
\text { equity on } \\
\text { type } A \\
\text { loan }\end{array}$ & $\begin{array}{l}\text { Residual } \\
\text { insurer } \\
\text { equity on } \\
\text { type B } \\
\text { loan }\end{array}$ & $\begin{array}{l}\text { Market } \\
\text { value of } \\
\text { insurer } \\
\text { equity for } \\
\text { type A loan }\end{array}$ & $\begin{array}{c}\text { Market } \\
\text { value of } \\
\text { insurer } \\
\text { equity for } \\
\text { type B loan }\end{array}$ \\
\hline 1 & 0.05 & 1.5 & 4.5 & 1.5 & 0 & 3 & 0 & 0.15 \\
\hline 2 & 0.1 & 4 & 5 & 4 & 0 & 1 & 0 & 0.1 \\
\hline 3 & 0.2 & 5 & 5 & 5 & 0 & 0 & 0 & 0 \\
\hline 4 & 0.3 & 5 & 5 & 5 & 0 & 0 & 0 & 0 \\
\hline 5 & 0.2 & 5 & 5 & 5 & 0 & 0 & 0 & 0 \\
\hline 6 & 0.1 & 5 & 4 & 4 & 1 & 0 & 0.1 & 0 \\
\hline 7 & 0.05 & 4.5 & 1.5 & 1.5 & 3 & 0 & 0.15 & 0 \\
\hline \multicolumn{2}{|c|}{$\begin{array}{l}\text { Market loan } \\
\text { value: }\end{array}$} & 4.7 & 4.7 & & & & & \\
\hline \multicolumn{2}{|c|}{$\begin{array}{l}\text { Market value of } \\
\text { contract funding: }\end{array}$} & & & 4.45 & & & & \\
\hline \multicolumn{2}{|c|}{$\begin{array}{l}\text { Equity capital } \\
\text { requirement } \\
(\mathrm{ECR}) \text { : }\end{array}$} & & & & & & 0.25 & 0.25 \\
\hline \multicolumn{2}{|c|}{$\begin{array}{l}\text { ECR percent of } \\
\text { loan value: }\end{array}$} & & & & & & $5.62 \%$ & $5.62 \%$ \\
\hline
\end{tabular}

Minimum regulatory capital requirement and distribution of equity value for a representative insurer. Equity Capital Requirement (ECR) is the market value of a loan of par value 5 euros (4.7 euros) less the market value of funding raised by issuance of contingent (insurance) contracts on four observable economic events (4.45 euros).

euros. Equivalently, the capital requirement that provides zero solvency risk for the representative insurer is 5.62 per cent of the market value of the loan.

\section{Liquidity, efficiency and capital requirements for banks and insurers}

Using the capital requirements above, we can now compare the differences in the respective requirements for banks and insurers, deduce the magnitude of the liquidity and efficiency losses that suboptimal regulation could induce, and illustrate the 
capacity of alternative incentive-based capital regulations to increase both the liquidity provided by banks, through their effect on the volume of riskless deposits, and the efficiency gains offered to investors by insurers, through their effect on the issuance by insurers of a complete set of state-contingent contracts.

\section{Comparing prudential capital requirements under functional regulation}

The minimum values of capital that a bank and an insurer must, respectively, hold, against an identical portfolio of assets in order that each display a zero probability of solvency risk are strikingly different. Regulators must impose on banks a 68.09 per cent minimum capital requirement against a loan with a par value of 5 euros in order that deposits issued by the bank bear no risk of default. The minimum capital required to render riskless the liabilities of an insurer holding the same loan is only 5.62 per cent. This remarkable difference in capital required of banks relative to insurers increases with the par value of the asset held by each type of intermediary.

While this difference in capital requirements against credit risk could hardly be more surprising, the intuition underlying it is elementary. It also stands in direct contrast to the focus of Basel I- and Basel II-based capital standards.

The solvency risk posed by any financial intermediary depends on its entire portfolio, and this portfolio consists of both assets and liabilities. Risk-based capital requirements under both the original Basel accord and its amendments, as well as under the new Basel II provisions, focus, however, on the credit risk posed by assets. This reflects the orientation of banking regulators toward those intermediaries (depositories), which raise most of their funds through deposits, and a policy objective, common to banking regulators in most economies, of minimizing the credit risk of deposits. Consistent with the role of real banks simultaneously providing both a riskless security to depositors/investors and payments services to those investors in the form of deposits, which serve as a medium of exchange, the idealized banks in our model economy fund their assets through issuing liabilities in the form of deposits. By virtue of their dual role, deposits must pay their par value in every future state of nature. Under conditions of moral hazard or other sources of market incompleteness, the volume of funds that banks can raise through riskless deposits is necessarily limited by the payoff of their assets in the most adverse state of nature.

Once recognition is taken of the inherent difference between depositories and other financial intermediaries, such as insurers and reinsurers, which finance the bulk of their assets through the issuance of such explicitly contingent liabilities as insurance contracts, the distortions inherent in applying Basel-type capital requirements to such intermediaries, or measuring their solvency risk by gauging the capital they would need to hold if subject to Basel-type requirements, is clear. Purchasing assets with funds raised through the alternative provision of insurance contracts or other contingent liabilities, these intermediaries can exhibit a complete absence of solvency risk while holding considerably less capital than banks, even when both types of institutions hold identical assets. In contrast to the Basel approach, the reason for the advantage of insurers and reinsurers lies in the contingent nature of their liabilities, which need not fully pay off across all future states but instead must pay their par 
value only when certain states occur, in which the payoff of the assets held by the intermediary is relatively high.

While our model is highly stylized for expositional purposes, the intuition of this result is obviously quite general. A riskless claim is the most restrictive of all financial claims that can be offered, as the solvency of a unit claim must span all possible states of nature. The percentage of a loan that must be financed with equity will increase continuously with the number of distinct states in which a liability is required to pay a constant contractual value. Since contingent liabilities, such as insurance contracts, need payoff in only a small number of states, in which asset values are higher than in all but the most adverse state, insurers can exhibit the same minimal degree of solvency risk as a regulated depository while holding substantially small amounts of capital, and, this required, the level of capital will decline as the partition of states in which the insurance liabilities becomes finer. ${ }^{23}$

\section{Systemic risk, efficiency losses and limits to financial trading}

As a focus of regulatory concern over potential efficiency losses to participants in both financial and real markets, "systemic risk" is, fundamentally, a consequence of the inability of agents to trade a sufficient volume of securities across all states of nature. We analyse, in the context of our simple model, the implications of the prudential capital regulations derived above on these two aspects of welfare loss identified with systemic risk. Specifically, we first examine a welfare loss associated with inadequate liquidity, represented by the inability of financial intermediaries, namely depositories, to offer as large a volume of riskless claims, tradeable by investors across all future states, as they could in the absence of moral hazard. We then examine the loss in efficiency represented by the inability of financial intermediaries, namely insurers, to offer a set of state-contingent contracts that span all future states. We interpret the relatively small volume of riskless securities in circulation and the inability of investors to hedge their uncertainty through spanning as an approximate analogue to the welfare losses that are engendered in those situations, interpretable as the occurrence of systemic risk, when intermediaries refuse to trade financial claims under stressful market conditions.

We note that complete transparency, if it occurred, would remove the effects of informational asymmetry as a source of inefficiency and systemic risk in this economy. The complication, of course, is that banks and other intermediaries offering standard

${ }^{23}$ Conversely, if the number of states in which such a liability would be required to pay a fixed amount increased, holding asset risk constant, so would the equity capital requirement of the insurer. If an insurer wished to issue liabilities similar to deposits, paying off across all states, then in this limiting case the capital requirements of the insurer would converge to those of a bank holding identical assets. Observe also that, while bank leverage can be increased by allowing the issuance of subordinated debt, in practice bank regulators focus attention on the probability of bank solvency, rather than the solvency of deposits. Bank leverage is, consequently, limited in practice by limits on the issuance of defaultable debt. While such limits are often justified in terms of mitigating efficiency losses under asymmetric information ("systemic risk"), the results below illustrate that they may themselves be inefficient in this role and that alternative, incentive-based regulations may actually increase both liquidity and efficiency (spanning). 
debt and equity claims have no incentive or credible means by which to signal their private information to market investors. This suggests that a form of regulatory capital requirements could enhance efficiency, if such requirements could give intermediaries an incentive to improve transparency and if this incentive was common knowledge to investors. Unfortunately, it is impossible, as we illustrate, to remove either aspect of systemic risk with traditional regulatory capital requirements alone.

While asymmetric information, in the form of moral hazard, has no influence on the pricing of loans to firms in our economy, it does significantly limit the incentives of either type of intermediary to pass on the benefits of lending diversification to investors. The volume of riskless financial claims (deposits) that they can offer will be significantly limited, relative to the potential value of claims that could be available, and a similarly smaller number of securities offering distinct payoffs across future states will also be issued. Specifically, as illustrated in Table 9, moral hazard limits the volume of riskless deposits to 150 euros, and limits the volume of insurance contracts for each specified pair of states to half the value of aggregate production occurring in those respective pairs of states. A measure of the benefits of diversification, obtained through the pooling of claims on type A and B firms by intermediaries in the absence of moral hazard (or equivalently in a situation in which intermediaries could make their portfolio strategies transparent through credible signaling to investors), is the ability of banks to offer 300 euros of riskless claims (deposits), rather than the 150 euros otherwise available, and the ability of insurers to offer contingent liability (insurance) contracts with aggregate values equal to aggregate production in each state.

Since investors will, in the absence of some means by which intermediaries could render their portfolio holdings transparent, assume that intermediaries will exploit potential gains from moral hazard by holding concentrated loan portfolios and so will impose a discount on the liabilities of the intermediary, and since such an assumption will require the intermediary to hold such concentrated portfolios if they are to issue fairly priced claims, equilibrium in the presence of the traditional capital requirements derived above will exhibit the limited volume and diversity of financial claims illustrated in Table 9. These limits could be a significant source of dead weight loss in this economy, restricting the opportunities of investors to optimize their date one consumption profiles across states.

\section{Increasing liquidity and efficiency through incentive-based capital regulations}

An increase in the issuance of riskless claims would, for example, become possible if regulators, recognizing the diversification benefits in lending, allowed the maximum deposit funding support of Min(par value, 2) for every paired loan, where par value is the value of each type A and type B loan pair. Investors, understanding the incentives faced by intermediaries, would impose the competitive market deposit limit of Min(par value, 5) in the absence of either an external guarantee on liabilities or a means by which intermediaries could credibly convey their portfolio holdings. ${ }^{24}$ Consequently,

${ }^{24}$ Moreover, in this situation, if banks were given the ability to continue to offer subordinated debt 
Table 9 Limits to trade imposed by asymmetric information

\begin{tabular}{lccccccc}
\hline State & Probability & $\begin{array}{c}\text { Type } A \\
\text { project } \\
\text { production }\end{array}$ & $\begin{array}{c}\text { Type } B \\
\text { project } \\
\text { production }\end{array}$ & $\begin{array}{c}\text { Aggregate } \\
\text { production }\end{array}$ & $\begin{array}{c}\text { Aggregate } \\
\text { available insurance } \\
\text { contracts }\end{array}$ & $\begin{array}{c}\text { Aggregate } \\
\text { riskless } \\
\text { production }\end{array}$ & $\begin{array}{c}\text { Aggregate } \\
\text { available bank } \\
\text { deposits }\end{array}$ \\
\hline 1 & 0 & 1.5 & 4.5 & 300 & 150 & 300 & 150 \\
2 & 0 & 4 & 9 & 650 & 400 & 300 & 150 \\
3 & 0 & 5 & 12 & 850 & 500 & 300 & 150 \\
4 & 0 & 10 & 10 & 1,000 & 1,000 & 300 & 150 \\
5 & 0 & 12 & 5 & 850 & 500 & 300 & 150 \\
6 & 0 & 9 & 4 & 650 & 400 & 300 & 150 \\
7 & 0 & 4.5 & 1.5 & 300 & 150 & 300 & 150 \\
\hline
\end{tabular}

Stock of alternative (riskless) financial claims available in model economy, under risk-neutral distribution, owing to asymmetric information.

traditional regulatory policy can increase the volume of riskless deposits only by simultaneously lowering capital requirements and accepting expected losses to a guarantee fund. ${ }^{25}$

An alternative to such actions would be to increase transparency through the creation of a regulatory regime through which, by the provision of appropriate incentives to intermediaries, the intermediaries can credibly signal their portfolio holdings to investors. One such incentive-based regulatory regime involves ex post taxation schedules, which require no additional information on the part of regulators but which reduce or entirely remove the period one gains from holding a concentrated loan portfolio. Assuming the implementation of such ex post taxation is also credible to investors, regulators could lower capital requirements on banks to that level commensurate with the true benefits to loan diversification, increasing liquidity through increasing the volume of riskless deposits in circulation, but without incurring claims against a public guarantee on bank liabilities. Regulators could also implement analogous ex post taxation schedules for insurers and reinsurers, giving these intermediaries an incentive to issue state-specific securities, based on their knowledge of individual firm production. Insurers, consequently, could complete asset markets. ${ }^{26}$

contracts, banks would in effect be required by the market to hold a concentrated exposure if they wanted to issue fairly priced subordinated debt claims as investors would still apply a moral hazard (default risk) discount to these liabilities.

25 A general taxation scheme that charges all investors or all firms might fund the guarantee, or, alternatively, regulators might adopt a specific ex post tax on solvent banks, but both means of taxation will still leave banks with adverse incentives from opportunities to exploit moral hazard (Nickerson and Van Order, 2004).

${ }^{26}$ We note, in passing, that Pillar 3 of the New Basel Capital Accord proposal reflects an increase in the regulatory focus on transparency, and recent proposals have been made in the U.S. Congress to mandate additional disclosures by non-bank intermediaries, including the housing GSEs. While the optimality of the transparency solution is clear in the context of this model, mandatory disclosures of portfolio transactions cannot eliminate moral hazard, owing to both the inability of such mandates to fully specify the range of contingencies relevant to the valuation of assets and the rapidity with which portfolio strategies can change. Achieving transparency requires, instead, that intermediaries can credibly signal their true asset diversification strategy to their debtholders. 
516

Although only firms and intermediaries retain the ability to directly observe the realization of individual states in period one, while regulators and investors only observe the realized value of aggregate production, regulators can apply their knowledge, as illustrated in Table 4, of the risk-neutral probabilities for each of the seven possible states (state-contingent prices) and the contingent production of each project type in each of these seven states, to determine the current (date zero) market value of a diversified loan portfolio and of a concentrated loan portfolio. Using these values in conjunction with knowledge of the volume of deposits being used to fund the loan portfolio allows the regulator to determine the respective values of each portfolio to bank shareholders, and consequently the "excess" value that bank shareholders would receive from holding a concentrated loan portfolio, should investors deem their claim credible. If a bank claims, in period zero, to hold a diversified portfolio but exhibits gains commensurate with a concentrated portfolio for a particular realization of aggregate production, regulators will tax away these excess gains, leaving shareholders indifferent between holding the two alternative portfolios. If this ex post taxation is credible to investors, then, since banks have no remaining incentive to concentrate their portfolios, investors will value deposits as riskless in equilibrium.

Columns 3-5 of Table 10 illustrate this policy for the case of a portfolio of 2 par 5 euro loans, financed with 6 euros in deposits. The value to bank shareholders of a diversified portfolio, with loans made to a type A and a type B firm, is 3.40 euros, while a portfolio of two loans made to two type A firms would hypothetically be 3.55 . The shareholder benefit from loan concentration is removed by imposing an ex post tax on the bank in those states in which its equity income exceeds the equity income it would earn on a perfectly diversified loan portfolio, which is the portfolio to which it must commit to quality for regulatory permission to accept greater deposit funding. In the example in Table 10, if a tax rate set at 15 per cent of income in excess of the bank's portfolio income is levied, the bank shareholders no longer accrue gains from concentrating the bank's loan portfolio. ${ }^{27}$

Similar results will occur from an incentive-based approach in the case of insurance regulation. An analogous taxation structure (with minimum equity limits) can be used to create a credible signalling mechanism that enables investors to identify insurers and reinsurers that hold well-diversified asset portfolios, precisely as done for banks.

Assuming that banks continue to act to issue riskless deposits while insurers specialize in state-contingent securities, a further result of applying contingent penalties can immediately be observed by considering how the market would evaluate a claim issued by an insurer that promised a payoff in one and only one specific state. Consider, as illustrated in Table 10, an insurer wishing to fund a loan to a firm of 5 euros par value, and issuing a liability that designated a payoff of 1.5 euros in state

\footnotetext{
${ }^{27}$ An interesting feature of this incentive-based approach is that, not only does it allow for a larger share of loan value to be funded with deposits and for the issuance of an efficient volume of riskless claims without the potential for any deposit insurance losses, but the increased share of deposit funding will provide an accurate signal to the secondary market for risky bank claims, such as equity or subordinated debt, and banks will be able to issue risky claims that reflect their diversified loan portfolios at fair market terms. The issuance of equity or subordinated debt by a diversified bank is no longer costly as the moral hazard pricing discount is removed by the taxation schedule.
} 
Table 10 Incentive-compatible taxation schedules for banks and insurers

\begin{tabular}{|c|c|c|c|c|c|}
\hline State & Probability & $\begin{array}{c}\text { Bank equity value } \\
\text { of diversified } \\
\text { portfolio }\end{array}$ & $\begin{array}{c}\text { Bank equity value } \\
\text { of concentrated } \\
\text { portfolio }(A)\end{array}$ & $\begin{array}{l}\text { Excess value to bank } \\
\text { from concentration } \\
\text { (type } A \text { loans) }\end{array}$ & $\begin{array}{c}\text { Expected value to insurer } \\
\text { from misrepresentation } \\
\text { (type A loans) }\end{array}$ \\
\hline 1 & 0.05 & 0 & 0 & 0 & 0.075 \\
\hline 2 & 0.10 & 3 & 2 & -1 & 0.4 \\
\hline 3 & 0.20 & 4 & 4 & 0 & 1 \\
\hline 4 & 0.30 & 4 & 4 & 0 & 0 \\
\hline 5 & 0.20 & 4 & 4 & 0 & 1 \\
\hline 6 & 0.10 & 3 & 4 & 1 & 0.4 \\
\hline 7 & 0.05 & 0 & 3 & 3 & 0.075 \\
\hline \multirow{2}{*}{\multicolumn{2}{|c|}{$\begin{array}{l}\text { Equity value } \\
\text { Ex ante gains from } \\
\text { moral hazard }\end{array}$}} & 3.40 & 3.55 & 3.55 & \\
\hline & & & 0.15 & 0.15 & 2.95 \\
\hline \multicolumn{2}{|c|}{ Ex post tax } & & & 0.15 & 2.95 \\
\hline
\end{tabular}

Regulatory ex post taxation schedules in model economy for banks funding loan portfolios with six euros in deposits and for insurers funding loan portfolios through contingent contracts with single-state payoffs.

one. Able to observe only a realization of aggregate output, investors know that 300 of aggregate production corresponds to the realization of either state one or state eleven in the model economy, but cannot discern which has actually occurred. They will, however, assume that the insurer will adopt whichever strategy - misrepresentation of the true state or truthful revelation of that state - leads to a higher ex post equity value on this loan. The date one value to the insurer of misrepresenting a state 1 realization by claiming the realization of state 11 , its complement, will lead to an expected gain of 0.3 in equity on this loan, while a strategy of truthful revelation will lead to an expected gain of 0.225 . A penalty of 0.075 on the issuance of this security, consequently, will leave the insurer indifferent between misrepresentation and truthful revelation. A similar argument applies to every security with a single-state payoff. An ex post taxation schedule could, consequently, be imposed, in conjunction with regulatory requirements of the type described in Table 7, that would make truthful revelation a (weakly) dominant strategy for each insurer. This would allow these intermediaries to issue securities spanning all states and, consequently, complete markets.

\section{Concluding remarks}

Although the specter of systemic risk ensuing from the operations of large financial institutions, and identified with losses in both liquidity and wealth owing to asymmetric information among financial market participants, is a popular notion, surprisingly little rigour is exhibited in discussions among policymakers, regulators and in the business press, of the nature of such risk, its causes and its mitigation. Proposals to use approaches towards the regulation of depositories to "harmonize" capital regulations for different types of financial institutions participating in the same financial markets, as well as measuring the capital adequacy of intermediaries like 
insurers and reinsurers in terms of capital requirements for banks, is increasingly a principal focus of policymakers and financial regulators.

The effects of systemic risk, including contagion between markets for different financial assets and the externalities this inflicts on real economic activity, are inevitably identified with asymmetric information among market participants. On a fundamental level, consequently, such risk exists because asset market incompleteness precludes investors from hedging against such risk and because informational asymmetries restrict the volume of securities which financial institutions can feasibly offer to investors.

We show, in the context of a simple two-period, finite-state model of financial exchange under moral hazard, two fundamental results. First, regulatory capital requirements designed primarily on the basis of asset credit risk, such as those in the Basel II proposals, cannot, in isolation, mitigate the losses in liquidity and efficiency stemming from asymmetric information among investors and intermediaries. Second, the application of capital regulations designed for depositories to assess the solvency risk of intermediaries issuing relatively larger proportions of contingent or structured liabilities, like insurance and reinsurance firms, is distortionary, as solvency risk is a function of the overall portfolio of a financial institution and such capital regulations take no account of differences between the liabilities respectively issued by banks and insurers. Harmonization of capital requirements for all financial intermediaries, based on the approach used in bank regulation, could consequently lead to a reduction in aggregate liquidity, as represented here by the volume of riskless securities offered to investors, as well as direct efficiency losses through restrictions on hedging, as represented here by the inability of intermediaries to issue of a complete set of state-contingent securities. This combination of illiquidity and limited spanning exacerbates, rather than reduces, systemic risk. These results will, obviously, only be amplified in more complex models of financial exchange.

This point, of course, applies to the regulation of all financial intermediaries which issue significant volumes of contingent liabilities. When the portfolio position of a class of intermediaries is further complicated by interest rate (price), tort and other forms of risk, such as with the case of insurance and reinsurance firms, the less applicable are Basel-type regulations to measure solvency risk and the less desirable is the harmonization of capital requirements based on a Basel-type approach.

\section{Acknowledgements}

We thank Mark Flannery, Robert Gibbons, Tanweer Hasan, Art Hogan, Martin Hellwig, Knut Hohlfeld, Patrick Liedtke, David Nebhut, William Stephens, Hung Tran, Brian Woodrow and participants at the 2003 Annual Meetings of the American Risk and Insurance Association, the joint IIF/IMF 2004 Symposium on International Solvency Standards and Financial Stability and at seminars at the Bank of England, the Congressional Budget Office, the Fannie Mae Foundation, the Office of Thrift Supervision, and Colorado State University for helpful comments. The first author wishes to acknowledge research support given to him while he was Deputy Division Chief of the Banking Regulation Division, Monetary and Exchange Affairs Department, International Monetary Fund, and the second author wishes to acknowledge support given to him by the Mission and the Capital Oversight and Economics Divisions of Freddie Mac, where he was Principal Economist. The usual disclaimer applies and, in particular, the opinions expressed here are those of 
the authors and do not necessarily reflect the views of the FDIC, the International Monetary Fund, Fannie Mae or Freddie Mac.

\section{References}

Basel Committee on Banking Supervision (1988) International Convergence of Capital Measurement and Capital Standards, Basel: Bank for International Settlements, July.

Basel Committee on Banking Supervision (1999) Credit Risk Modeling: Current Practices and Applications, Basel: Bank for International Settlements, April, p. 13, from http://www.bis.org/publ/bcbs49.pdf.

Basel Committee on Banking Supervision (2004) International Convergence of Capital Measurement and Capital Standards: A Revised Framework, Basel: Bank for International Settlements, June.

Booth, P. (2002) Risk and capital for banks and insurers, working paper, London: Financial Industry and Regulation Division, Bank of England.

Cummins, J., Phillips, R. and Smith, S. (1996) Corporate hedging in the insurance industry: The use of financial derivatives by US insurers, working paper, Philadelphia: Wharton School, University of Pennsylvania.

Davies, H. (2001a) The role of financial regulators in promoting financial stability, Speech to the Insurance Institute of London Annual Luncheon, March, London: Financial Services Authority Press Release, from http://www.fsa.gov.uk/pubs/press/2001/031.html.

Davies, H. (2001b) Integrated financial regulation: lessons from the U.K.'s financial services authority, Speech to the Centre for Financial Studies Seminar, Commersbank AG, August, London: Financial Services Authority, from www.fsa.gov.uk/pubs/speeches/index-2001.html.

Davies, H. (2002) Strengthening of insurance industry's capital base needed, Speech to the Association of Insurance and Risk Managers, January, London: Financial Services Authority Press Release PN/011, from http://www.fsa.gov.uk/pubs/press/2002/011.html.

Diamond, D. (1984) 'Financial intermediation and delegated monitoring', Review of Economic Studies LI(September): 393-414.

European Commission (2002) Solvency II: Review of work, Financial Institutions paper MARKT/2518/02EN, Brussels, from http://europa.eu.int/comm/internal_market/.

FDIC (2000) Federal Deposit Insurance Corporation DO $\bar{S}$ Manual of Exam Policies, Section 2.1, Capital, Washington, DC: Federal Deposit Insurance Corporation, Department of Supervision, from http:// www.fdic.gov/regulations/safety/manual/99CAPITA_main.htm.

Financial Services Authority (2000) Insurance Draft Interim Prudential Sourcebook, London.

Financial Services Authority (2004) Enhanced capital requirements and individual capital assessments for nonlife insurers, Consultation paper 190, London.

Fisher, P. (2002) 'Back to basics: credit matters', Remarks of Treasury Under Secretary Peter Fisher to the FDIC Symposium, The Rise of Risk Management: Basel and Beyond, Press Release PO-3305 (31 July), Office of Public Affairs, United States Department of the Treasury, Washington, DC.

Frame, W. and Wall, L. (2002) 'Financing housing through government-sponsored enterprises', Economic Review 86 (First Quarter, Federal Reserve Bank of Atlanta): 29-43.

GAO (1991) 'Government sponsored enterprises: a framework for limiting government exposure to risks', General Accounting Office Report to Congress, Washington, DC.

Gensler, G. (2000) Testimony of Treasury Under Secretary Gary Gensler to the House Banking Subcommittee on Capital Markets, Securities and Government Sponsored Enterprises, Press Release LS-479, March, Washington, DC: Office of Public Affairs, United States Department of the Treasury.

Guy Carpenter and Company (2004) Convergence in Capital Adequacy Measures and Financial Reporting Rules, August, London and New York: Marsh \& McLennan Companies.

Greenspan, A. (1998) 'The role of capital in optimal banking supervision and regulation', Federal Reserve Bank of New York Economic Policy Review (October): 163-168.

Group of Ten (2001) Report on Consolidation in the Financial Sector, Washington, DC: International Monetary Fund and Basel; Switzerland: Bank for International Settlements (http://www.imf.org/ external/np/g10/2001/01/eng/pdf/FSCSsum.pdf).

Harrison, M. and Pliska, S. (1981) 'Martingales and stochastic integrals in the theory of continuous trading', Stochastic Processes and their Applications 11: 313-316. 
Hohlfeld, K. (2004) 'International standard setting', Presentation at the Symposium on International Solvency Standards and Financial Stability, November, Washington, DC.

Keefe, D. (2002) 'Insurance companies: on the road to Basel III', Risk 3(2) (March), from http:// db.riskwaters.com/public/showPage.html?page $=3858$.

Knight, M. (2004) 'Regulation and supervision in insurance and banking: greater convergence and shared challenges', Speech at the Eleventh Annual Conference of the International Association of Insurance Supervisors, October, Basel: Bank for International Settlements, from http://www.bis.org/speeches/ sp041006.htm.

Kupiec, P. and Nickerson, D. (2002) Assessing systemic risk exposure from banks, insurers and housing GSEs under alternative approches to risk-based capital regulation, working paper, December, Colorado State University, CO, U.S.A..

Milne, F. (1995) Finance Theory and Asset Pricing, Oxford: Oxford University Press.

NAIC (2000) Schedule DB, 1999 Annual Reports of US Insurers to the National Association of Insurance Commissioners Kansas City, MO, USA.

Nickerson, D. and Van Order, R. (2004) Double trouble: Joint liability and bargaining in deposit insurance since FDICIA, working paper, Roosevelt University.

Poole, W. (2002) 'Financial stability', Remarks of the President of the Federal Reserve Bank of St. Louis to the Council of State Governments, Southern Legislative Conference Annual Meeting, New Orleans, Louisiana, Office of Public Affairs, Federal Reserve Bank of St Louis, St Louis, MO, from http:// www.stls.frb.org/news/speeches/2002/08_04_02.html.

Sharma, P. (2002) Prudential Supervision of Insurance Undertakings, Conference of Insurance Supervisory Services of the Member States of the European Union, December.

Spulber, D. (1996) 'Market microstructure and intermediation', Journal of Economic Perspectives 10(3) (Summer): 135-152.

Tietmeyer, H. (1999) Report to the Finance Ministers and Central Bank Governors of the G-7, Bonn: Deutsche Bundesbank.

Tiner, J. (2002) Less Is More Should Be Motto for Insurance Regulation, Speech at the FSA Conference on Reforming Insurance Regulation, February. London: Financial Services Authority Press Release PN/022, from http://www.fsa.gov.uk/pubs/press/2002/022.html.

Werner, J. (1987) 'Arbitrage and the existence of competitive equilibrium', Econometrica 55(6) (November): 1403-1418.

\section{About the Authors}

Paul Kupiec is Associate Director of the Division of Insurance and Research at the Federal Deposit Insurance Corporation in Washington, DC, U.S.A. His current research interests focus on risk measurement, capital allocation models, and the management and regulation of financial institutions. His former positions include Deputy Chief of the Banking Supervision and Regulation Division in the Monetary and Exchange Affairs Department of the International Monetary Fund, principal economist at Freddie Mac, vice-president at J.P. Morgan's in the RiskMetrics group, Senior Economist in Trading Risk Analysis Section at the Federal Reserve Board, Visiting Economist at the Bank for International Settlements in Basel, Switzerland, and Assistant Professor of Finance at North Carolina State University. He is widely published in professional risk management and academic finance journals. Dr. Kupiec received a Ph.D. in Economics from the University of Pennsylvania in 1985.

David Nickerson is the Marshall Bennett Chair and Professor in the School of Accounting and Finance at Roosevelt University in Chicago, IL, U.S.A. His current research interests include risk-based regulation of financial institutions, the value of guarantees under alternative capital regulations, and efficiency and competition in 
intermediated markets. Current and former positions held by Dr. Nickerson include Principal Economist at Freddie Mac, Senior Financial Economist at the Office of Thrift Supervision, Professor of Economics and Finance at Colorado State University, University of British Columbia and Duke University, and Visiting Scholar at the Federal Reserve Banks of Kansas City and St. Louis. He is widely published in academic economics and risk journals. Dr. Nickerson received a Ph.D. in Economics from Northwestern University in 1982. 